\title{
Multi-Scale Organization of the Drosophila melanogaster Genome
}

\author{
Samantha C. Peterson +(D), Kaylah B. Samuelson ${ }^{+}(\mathbb{D}$ and Stacey L. Hanlon * (D) \\ Department of Molecular and Cell Biology, University of Connecticut, Storrs, CT 06269, USA; \\ samantha.c.peterson@uconn.edu (S.C.P.); kaylah.samuelson@uconn.edu (K.B.S.) \\ * Correspondence: stacey.hanlon@uconn.edu \\ † These authors contributed equally to this work.
}

check for updates

Citation: Peterson, S.C.; Samuelson, K.B.; Hanlon, S.L. Multi-Scale Organization of the Drosophila melanogaster Genome. Genes 2021, 12, 817. https://doi.org/10.3390/ genes12060817

Academic Editors: Maria Sharakhova and Vladimir Trifonov

Received: 30 April 2021

Accepted: 26 May 2021

Published: 27 May 2021

Publisher's Note: MDPI stays neutral with regard to jurisdictional claims in published maps and institutional affiliations.

Copyright: (c) 2021 by the authors. Licensee MDPI, Basel, Switzerland. This article is an open access article distributed under the terms and conditions of the Creative Commons Attribution (CC BY) license (https:/ / creativecommons.org/licenses/by/ $4.0 /)$.

\begin{abstract}
Interphase chromatin, despite its appearance, is a highly organized framework of loops and bends. Chromosomes are folded into topologically associating domains, or TADs, and each chromosome and its homolog occupy a distinct territory within the nucleus. In Drosophila, genome organization is exceptional because homologous chromosome pairing is in both germline and somatic tissues, which promote interhomolog interactions such as transvection that can affect gene expression in trans. In this review, we focus on what is known about genome organization in Drosophila and discuss it from TADs to territory. We start by examining intrachromosomal organization at the sub-chromosome level into TADs, followed by a comprehensive analysis of the known proteins that play a key role in TAD formation and boundary establishment. We then zoom out to examine interhomolog interactions such as pairing and transvection that are abundant in Drosophila but rare in other model systems. Finally, we discuss chromosome territories that form within the nucleus, resulting in a complete picture of the multi-scale organization of the Drosophila genome.
\end{abstract}

Keywords: Drosophila; topologically associating domain; insulator; pairing; transvection; B chromosome; cytogenetics

\section{Introduction}

Within the nucleus, the labyrinth of threads that comprise the genome does not, at first glance, appear to be organized. Indeed, when Walther Flemming initially described the dynamics of the material he called 'chromatin,' he designated one of the stages he observes as the 'skein stage' in an apparent reference to how the chromatin appears like a coiled and tangled skein of yarn [1]. From the observer's perspective, one may conclude that order is eventually achieved as the cell moves into mitosis and the chromatin condenses into structured, discrete chromosomes; after their alignment and segregation into separate daughter cells, the chromosomes then dissolve back into a disorganized state within the nucleus.

From the chromosome's point of view, however, the complete opposite is true. Despite its disordered appearance, chromatin is subject to complex, multi-scale organization that we have only started to understand. Surprisingly, as we touch on below, many of the integral associations that promote chromosomal organization disappear when chromatin condenses into individual chromosomes during cell division. Advancements in cytological techniques and DNA sequencing applications have challenged our definition of what it means for a genome to be organized and are revealing how chromosomes self-organize, as well as how and when they interact with their homolog and form discrete territories within the nucleus. Fueled by this acceleration of more sensitive tools for genomic investigation, the field of genome organization has exploded.

Remarkable strides in understanding genome organization have taken place in many model systems from all three domains of life [2-4]. In this review, we chose to concentrate our focus on the multi-scale organization of chromosomes in the model system Drosophila melanogaster (Figure 1). We will pay particular attention to how chromosomes interact 
with themselves through our review of the key players involved in the formation and maintenance of topologically associating domains, or TADs. We then discuss our current knowledge of interhomolog interactions as it relates to pairing, transvection, and chromosome territories that are formed within the nucleus. In exploring chromosome associations on the nucleotide-to-nucleus scale, a larger picture of the genome's organization from the perspective of the chromosome is revealed.

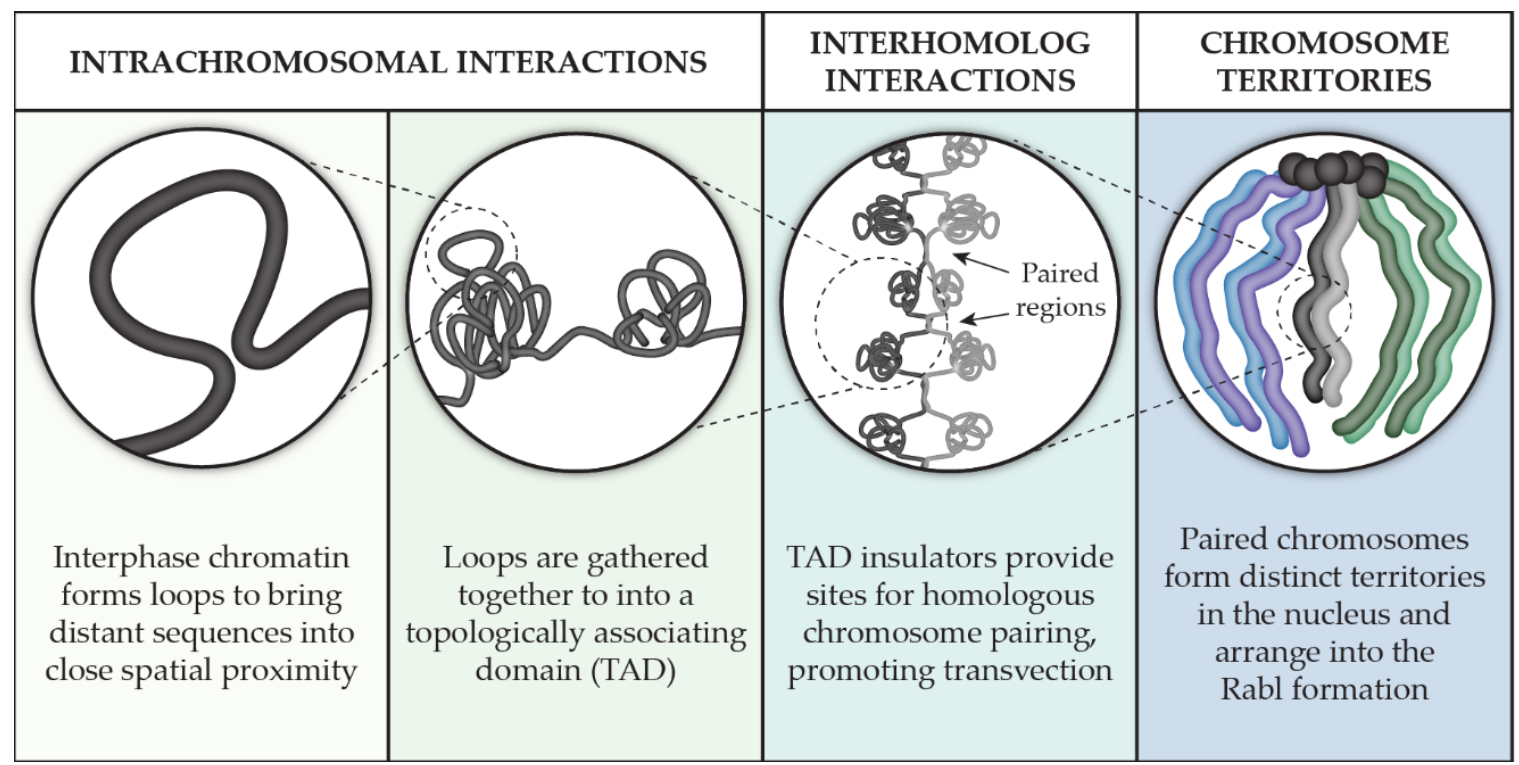

Figure 1. Genomic organization from the point of view of the chromosome.

\section{TADs in Drosophila}

When not compacted into chromosomes during cell division, the genome resides in the nucleus as chromatin that is highly dynamic [5]. The flexibility of the DNA in this thread-like state enables chromosomes to bend and loop into complex conformations that establish tight spatial associations in three dimensions between genomic regions that can be quite distant at the sequence level. The result is self-interacting domains that are enriched in internal chromatin contacts, especially when compared to surrounding domains. The associations that form these domains are not random as their spatial relationship, or topology, remains mostly consistent after several cell divisions and across cell types, leading to the name topologically associating domains (TADs). Below, we discuss the methodology of TAD identification and how changes at the DNA level affect TAD dynamics. We will also go into detail about the proteins in Drosophila that are currently known to be important for TAD formation, regulation, and maintenance.

\subsection{Sub-Chromosomal Organization and the Advent of TADs}

The movement of interphase chromatin observed in live cells displays an interesting behavior: though it is free to move via diffusive random walk motion, this motion appears to be confined to smaller subregions within the nucleus [6]. Despite this restriction, chromatin is capable of long-range interactions that are recurrent and functional [7]. To understand the 3D organization of the genome and investigate the conformation of chromosomes in interphase, a new technique was developed: chromosome conformation capture, or ' $3 C^{\prime}$ [ 8$]$. The underlying principle of this technique is to covalently link genomic sequences that are in close spatial proximity to one another and analyze the resulting fragments. This analysis can be on a small scale, such as probing for a single, specific interaction, as well as a genome-wide scale to examine the frequency of chromosomal contacts between all parts of the genome. The latter technique, generally referred to as 'Hi-C,' results in a visualization of chromatin organization on a genome-wide scale $[9,10]$. 
The arrival of advanced chromosome capture techniques that can detect chromosome contacts at the level of the whole genome revealed the complexity of chromosome interactions and transformed our view of genome organization. The chromosome contact map of domains in the Drosophila genome was soon after published [11], followed shortly by a pair of studies that examined chromosome contacts in mice and in human cells [12,13], the latter of which coined the term 'TAD.' Not only is this technique being applied routinely to compare genome organization across genotypes, cell types, and species but there has also been an emergence of variations of this technique that have the potential to add additional layers of information about the genome on top of the chromosome contact map [14,15]. For example, a new method called Hi-M has enabled the simultaneous capture of chromosome structure and transcriptional activity of a large $(\sim 350 \mathrm{~kb})$ region of the genome in Drosophila embryos [16], and Micro-C has been applied in yeast to generate chromosome contact maps at nucleosome-scale resolution [17]. With the evolution of these techniques, our understanding of the functional aspects of genome organization will continue to grow.

\subsection{Chromatin Context of TADs in D. melanogaster}

Drosophila melanogaster has more than 4000 TADs, ranging in size from 3 to $460 \mathrm{~kb}$ [18]. The general structure of a Drosophila TAD consists of a transcriptionally active region close to the TAD border and an inactive region contained within the TAD [19]. Consistent with this model, the promoters and bodies of housekeeping genes and active marks are found at TAD boundaries, while H3K27me3, histone H1, and core histone $\mathrm{H} 3$ levels are depleted from TAD boundaries [20]. TAD boundaries also behave like classic insulator elements in that they bind known insulator proteins and are found between divergent promoters, as well as having a strong correspondence to interband regions on polytene chromosomes [21].

TADs have been thought to exhibit some form of hierarchy, with low-level, smaller TADs being contained within larger, high-level TADs [20]. This may be reflective of superimposed alternate folding patterns obtained by Hi-C data from populations of Drosophila cells, however, and modern single-cell $\mathrm{Hi}-\mathrm{C}$ approaches have the potential to clarify this result [22,23]. Already, the single-cell Hi-C maps of Drosophila cell types have revealed more variability in interactions involving inactive chromatin, while interactions that were common in individual cells were composed of active chromatin. This makes sense as populations of the same cell type should have the same profile of active genes. Furthermore, boundaries that were conserved in one cell type tend to also be conserved in other cell types [22].

Despite the consistency of their boundary formation, TADs are likely dynamic in vivo as opposed to static [24,25]. In some situations, this flexibility can lead to unintended changes in TAD structure and regulation. For example, TADs associated with the nuclear lamina become more active and less compact and stretch toward the nuclear interior when the lamina is disrupted [26]. Additionally, chromatin is packed in the nucleus in interphase in inconsistent densities [27], and the chromatin architecture changes during the cell cycle [28], which has the potential to influence TAD behavior. In the Drosophila embryo, however, chromosome conformation and gene regulation were recently shown to be independent, and instead, TADs appear to fine-tune interactions between the promoters and enhancers of developmental genes [29,30].

Although there are many studies showing that chromatin marks are a prominent organizing factor in Drosophila [20,31,32], the exact mechanism of TAD formation remains unclear. It has been theorized that TADs can assemble themselves based on the level of histone acetylation: interactions are reduced between acetylated histones, while nonacetylated histones are more prone to interact, an effect that was sufficient for chromosome partitioning into TADs in computer models [31]. Separation of TADs may also be from methylation-or, more precisely, the lack thereof-as genomic regions with low H3K27me3 contain active housekeeping genes and are enriched for architectural proteins, whereas other regions with regulated genes, regardless of activity, have high or moderate levels of 
H3K27me3 [32]. It was predicted through polymer modeling that a dynamic loop extrusion mechanism is responsible for TAD formation, which consists of chromatin being pulled through a loop extruding factor (LEF) such as cohesin, until the LEF hits insulator proteins such as CTCF [24]. However, this process appears to be specific to mammals, with genome segregation being more essential to formation of TADs in Drosophila [19]. Interestingly, it has also been suggested that active transcription by RNA polymerase II plays a role in shaping Drosophila TADs, in conjunction with TAD boundary positions [33]. Hi-C at the sub-kb level suggests that epigenetic modifications are a factor for higher-order TAD folding, but the presence of pairs of insulator proteins was extremely predictive of a TAD boundary, and these may be more of a primary factor for the formation of individual TADs [18].

\subsection{Insulator Proteins Involved in TAD Formation, Regulation, and Maintenance}

In D. melanogaster, the overwhelming majority of TAD borders contain insulator elements $[18,21]$. The proteins and the sequences to which they bind are integral for the chromosome architecture in Drosophila, and in the following section, we make an effort to collate our current knowledge of insulators in detail. Drosophila has many insulator proteins, which we have cataloged in this review (Table 1). One of these insulator proteins is a homolog of mammalian CTCF (dCTCF), which, at present, is the only known protein responsible for insulator activity in vertebrates. dCTCF has a similar structure to vertebrate CTCF, including 11 zinc fingers, and is just as widely expressed in all tissues and developmental stages in Drosophila as in vertebrates [34]. Unlike CTCF in mammals, which can act on its own, dCTCF needs other proteins to insulate regions of chromatin [35]. Recently, it was found that depleting dCTCF in embryos causes domain boundary defects near CTCF-binding sites, and dCTCF acts to insulate promotors and enhancers, rather than play a direct role in transcription regulation [36].

Other important insulator proteins in Drosophila include Boundary element-associated factor 32 (BEAF-32), Chromator, and CP190. In Drosophila embryos, Chromator, dCTCF, CP190, and BEAF-32 were found to be factors in partitioning physical domains in the genome [11]. BEAF-32 was first identified by immunostaining at the borders of polytene chromosomes [37]. BEAF-32 is preferentially found at borders of active regions, and dCTCF is found at borders of polycomb group-mediated regions [11]. BEAF-32, CP190, and Chromator are also found to be enriched at TAD boundaries [18]. Interestingly, Chromator is also enriched at dCTCF sites, suggesting it plays a role in chromatin organization [38]. CP190 intermediates interactions between insulator proteins and promoter sequences [39]. CP190 induces chromatin unfolding, possibly by recruitment of dCTCF, in both Drosophila and mammalian cells [40], and there are nearly 9000 CP190 binding regions in Drosophila, which overlap with two thirds of the dCTCF binding regions [41]. CP190 co-localizes with GAF, Su(Hw), cohesin, and E(Z) (a polycomb protein) [41]. Chromatin-linked adaptor for MSL proteins (CLAMP) appears to interact primarily with CP190, due to the disruption of its localization in the nucleus upon loss of CLAMP, and loss of CP190 correlates with much less recruitment of CLAMP to chromatin [42]. Chromator and chromatin remodelers are found to be increased at TAD boundaries [20]. Chromator, BEAF-32, RNA polymerase, JIL-1 kinase, and constitutively active (housekeeping) genes are enriched at the polytene chromosome interbands and active histone marks [19].

Suppressor of Hairy Wing $(\mathrm{Su}(\mathrm{Hw}))$ and Modifier of $\operatorname{mdg} 4(\operatorname{Mod}(\operatorname{mdg} 4))$ are also implicated in TADs. Mod(mdg4) interacts with $\mathrm{Su}(\mathrm{Hw})$, an insulator protein, and is required for enhancer-promoter blocking [43]. GAGA factor (GAF) is known to interact with $\mathrm{Mod}(\mathrm{mdg} 4)$ to regulate $\mathrm{su}(\mathrm{Hw})$ insulators [44]. GAF also interacts with chromatin remodelers, transcription machinery, and polycomb response elements (PREs) [45], and GAF is necessary for the maternal-to-zygotic transition in embryos [46]. GAF, like M1BP, has many functions throughout the genome. Another architecture protein, Motif 1 Binding Protein (M1BP), was first discovered to be a transcription factor that recruits Pol II to promoters [47]. M1BP binding motifs are found to be enriched at TAD boundaries [48]. Recently, M1BP was found to interact with insulator proteins, mainly CP190, but also 
$\mathrm{Su}(\mathrm{Hw})$ and $\mathrm{Mod}(\operatorname{mdg} 4)$, at TAD boundaries [49]. Depletion of M1BP correlates with genome compaction, which shows that M1BP plays a role in chromatin accessibility and genome organization [49].

Other well-known Drosophila architectural proteins include the product of the zestewhite 5 gene (Zw5) [50], as well as Pita and zinc-finger protein interacting with CP190 (ZIPIC) [51]. Zw5 blocks enhancer-promoter interactions, but it is not strong enough to be an effective insulator by itself [50]. Pita and ZIPIC are insulators that directly interact with CP190 and help target it to promoters [51]. Pita was shown to interact with the BTB domain of CP190, whereas ZIPIC interacted with CP190 through a span of amino acids that included a part of its $\mathrm{M}$ domain [51].

Insulator proteins are often associated with specific epigenetics marks. H3K27me3dense regions frequently have $\mathrm{dCTCF}, \mathrm{GAF}$, and Mod(mdg4) at their borders in the Drosophila genome [52]. dCTCF appears to associate with other insulator proteins at H3K27me3 region borders throughout the genome, including BEAF-32, $\mathrm{Su}(\mathrm{Hw})$, and CP190 [38,41]. dCTCF and CP190 are correlated with nucleosome loss and chromatin opening, and the loss of dCTCF or CP190 is correlated with an increase in repressive histone marks, such as H3K27me3 [41]. BEAF binding sequences are typically located very close to transcription start sites of active genes and are associated with RNA Pol II, H3.3, and H3K4me2, but they are not associated with $\mathrm{Su}(\mathrm{Hw})$ and dCTCF [53].

There are two classes of insulator complexes, each of which has distinct regulation mechanisms [52]. Class I insulators are characterized by the binding of BEAF-32, CP190, or $\mathrm{ACTCF}$ and act to protect regions of active chromatin from the encroachment of silent chromatin [52]. BEAF-32 has since become known as an insulator of high importance in Drosophila evolution [54]. Class II insulators are those bound by $\mathrm{Su}(\mathrm{Hw})$ [52], and unlike Class I insulators, $\mathrm{Su}(\mathrm{Hw})$ does not colocalize with $\mathrm{Pol}$ II [55]. Instead, $\mathrm{Su}(\mathrm{Hw})$-associated insulators recruit chromatin remodeling complex Brahma and histone acetyltransferase complex SAGA, resulting in depletion of nucleosomes in Drosophila cell culture, and $\mathrm{Su}(\mathrm{Hw})$ also recruits origin recognition complex (ORC) to help initiate gene transcription [55].

One of the most well-studied insulator sequences is the gypsy retrotransposon. The gypsy insulator is named after its localization to the $5^{\prime}$ untranslated region of the gypsy retrotransposon. Two proteins fundamental to the gypsy insulator are $\mathrm{Su}(\mathrm{Hw})$ and $\mathrm{Mod}(\operatorname{mdg} 4)$ [56]. The gypsy insulator sequence has 12 places for $\mathrm{Su}(\mathrm{Hw})$ to bind, making the gypsy complex a class II insulator [57]. Centrosomal protein 190 (CP190) was later discovered to bind both $\mathrm{Su}(\mathrm{Hw})$ and $\mathrm{Mod}(\operatorname{mdg} 4)$ and is the third required component of the insulator complex [39]. $\mathrm{Su}(\mathrm{Hw})$ contains twelve zinc finger domains and interacts with Mod(mdg4) through its C-terminal region [58]. CP190 and Mod(mdg4) can interact through the BTB domain of $\operatorname{Mod}(\operatorname{mdg} 4)$ and the M domain of CP190 [58]. One of Mod(mdg4)'s domains that is rich in glutamine can interact with $\mathrm{Su}(\mathrm{Hw})$ 's $\mathrm{N}$-terminal domain [58]. CP190 also contains a BTB domain, through which it can interact with two adjacent sites on the $\mathrm{N}$-terminus of $\mathrm{Su}(\mathrm{Hw})$ [59].

These three insulator proteins interact with many other proteins as well. $\operatorname{Mod}(\operatorname{mdg} 4)$ interacts with Zeste through C-terminal and BTB domains, which appears to be required for enhancer-promoter communication of the white gene [60]. Enhancer of yellow $2(\mathrm{E}(\mathrm{y}) 2)$ also interacts with $\mathrm{Su}(\mathrm{Hw})$ and is required for barrier function of the 1A2 gypsy insulator [61]. This insulator activity is critical for proper expression of the yellow gene [62]. Heterochromatin protein 1 (HP1a) interacts with HIPP1 and associates with various insulator proteins including $\mathrm{Su}(\mathrm{Hw}), \mathrm{CP} 190$, and $\operatorname{Mod}(\operatorname{mdg} 4)$ [63]. However, interactions of HIPP1 and insulator complexes appeared to be distinct from interactions between HP1a and HIPP1 in heterochromatin [63]

$\mathrm{Su}(\mathrm{Hw}), \operatorname{Mod}(\operatorname{mdg} 4)$, and gypsy insulator sequences are found at the periphery of the nucleus, and it has been shown that inserting the gypsy insulator sequence causes a section of chromatin to relocate from the center of the nucleus to the periphery [64]. gypsy sequences also come together in long-distance interactions at the same location in the nucleus [64]. The gypsy insulator forms a loop, with the gypsy motifs and $\mathrm{Su}(\mathrm{Hw})$ binding 
sites located at the base of the loop, which was first suggested by Byrd and Corces in 2003 [65]. They also described the nuclear matrix as a skeletal network for the insulators to attach to and that it is necessary for loop formation, and they concluded that the gypsy insulator (primarily $\mathrm{Su}(\mathrm{Hw})$ and $\operatorname{Mod}(\mathrm{mdg} 4)$ ) forms loops by attaching to the nuclear matrix [65].

A second well-studied insulator complex is the late boundary complex (LBC). The LBC is a large $(>700 \mathrm{kDa})$ and more recently discovered complex that binds to Fab-7 sequences flanking the bithorax complex (BX-C). Architecture proteins CLAMP and GAF seem to depend on each other for binding to the Fab-7 boundary of the BX-C [66]. The LBC itself includes Mod(mdg4), GAF, and E(y)2 [67]. Furthermore, the LBC only seems to be necessary for the late embryonic development and adult stages of Drosophila [67]. The BX-C is one of the HOX gene complexes and is epigenetically silenced via a polycomb-repressed condensed TAD and polycomb response elements (PREs) that are in close proximity to each other, possibly reflecting the organization of the compacted structure by the PREs themselves contacting each other [68-70]. ELBA is another insulator complex that regulates the Fab-7 boundary during early development [71]. It is made up of three proteins: Elba1, Elba2, and Elba3, all of which are required for DNA binding and insulator activity [71]. BEN domains in Elba1 and Elba2 are responsible for DNA binding, and Elba3 is required for holding the two BEN domains together [71]. dCTCF, like the LBC, is also important for the correct regulation of the BX-C [72]. dCTCF regulates Fab-8 and expression of Abd-B in the bithorax complex [34].

The LBC has also been shown to bind to male-specific lethal (MSL) recognition sequences on the $\mathrm{X}$ chromosomes of males, including rox1 and rox2 [66]. rox1 and rox2 encode RNAs that are expressed in all somatic cells in male flies, localize with other MSL proteins along the $\mathrm{X}$ chromosome, and are likely required for the process of dosage compensation [73]. A study by Ramírez et al. indicated that TAD boundaries on the $\mathrm{X}$ chromosome correlate strongly with MSL complex binding sites in males [74]. Furthermore, the 3D organization of the $\mathrm{X}$ chromosome is very similar between males and females; therefore, the MSL complex likely does not alter the chromosome architecture, but merely acts upon what is already established [48]. CLAMP also interacts with rox1 [75] and has been shown to be associated with both the LBC and the gypsy complex [42,66]. Chromator appears to be a multifunctional protein that is associated with the MSL complex [76] and regulates polytene chromosome structure by direct association with JIL-1 kinase [77].

Table 1. Proteins involved in Drosophila TAD architecture. Gene names were acquired from FlyBase [78].

\begin{tabular}{|c|c|c|c|}
\hline Drosophila Gene Name & Alternative Name(s) & DNA Binding Activity & $\begin{array}{l}\text { Interactions with Other } \\
\text { Architectural Proteins }\end{array}$ \\
\hline $\begin{array}{l}\text { Boundary element-associated } \\
\text { factor of 32kD (BEAF-32) }\end{array}$ & $\begin{array}{c}\text { BEAF-32A/BEAF-32B (isoforms } \\
\text { of BEAF-32), BEAF, boundary } \\
\text { element-associated factor }\end{array}$ & $\begin{array}{l}\text { Yes via a BED finger } \\
\text { domain }[79,80]\end{array}$ & $\begin{array}{l}\text { Chromator [81] } \\
\text { CP190 [81] }\end{array}$ \\
\hline $\begin{array}{l}\text { Centrosomal protein } \\
\text { 190kD (Cp190) }\end{array}$ & $\begin{array}{l}\text { Rb188, DMAP190, Cen190, } \\
\text { CP-190, Centrosomal } \\
\text { Protein 190, CP190 }\end{array}$ & $\begin{array}{l}\text { Yes, via zinc finger } \\
\text { domains [39] }\end{array}$ & $\begin{array}{c}\text { BEAF-32B [81] } \\
\text { Chromator [81] } \\
\text { CLAMP [42] } \\
\text { dCTCF [82] } \\
\text { HIPP1 [63] } \\
\text { Mod(mdg4) [39] } \\
\text { Pita [51] } \\
\text { Su(Hw) [39] } \\
\text { ZIPIC [51] }\end{array}$ \\
\hline $\begin{array}{l}\text { Chromatin-linked adaptor for } \\
\text { MSL proteins (Clamp) }\end{array}$ & CLAMP & $\begin{array}{l}\text { Yes, via zinc finger } \\
\text { domains [83] }\end{array}$ & $\begin{array}{c}\text { CP190) [42] } \\
\text { Mod(mdg4) [42] } \\
\text { Su(Hw) [42] }\end{array}$ \\
\hline
\end{tabular}


Table 1. Cont.

\begin{tabular}{|c|c|c|c|}
\hline Drosophila Gene Name & Alternative Name(s) & DNA Binding Activity & $\begin{array}{l}\text { Interactions with Other } \\
\text { Architectural Proteins }\end{array}$ \\
\hline Chromator (Chro) & Chriz, Chro(Chriz) & None found & $\begin{array}{c}\text { BEAF-32B [81] } \\
\text { CP190 [81] } \\
\text { dCTCF [84] } \\
\text { JIL-1 kinase [77] } \\
\text { Mod(mdg4) [85] }\end{array}$ \\
\hline CTCF & dCTCF, CCCTC-binding factor & $\begin{array}{l}\text { Yes, via zinc finger } \\
\text { domains [34] }\end{array}$ & $\begin{array}{c}\text { Chromator [84] } \\
\text { CP190 [82] } \\
\text { E(y)2 [86] } \\
\text { HIPP1 [63] }\end{array}$ \\
\hline deformed wings (dwg) & $\begin{array}{c}\text { Zw5, 1(1)zw5, zw-5, EG:95B7.6 } \\
\text { zeste-white } 5\end{array}$ & $\begin{array}{l}\text { Yes, via zinc finger } \\
\text { domains [50] }\end{array}$ & (itself) [87] \\
\hline enhancer of yellow 2 (E(y)2) & $\begin{array}{l}\text { ENY2, late boundary } \\
\text { complex, LBC }\end{array}$ & None found & $\begin{array}{c}\text { dCTCF [86] } \\
\text { GAF [45] } \\
\text { Su(Hw) [61] }\end{array}$ \\
\hline $\begin{array}{l}\text { HP1 and insulator partner } \\
\text { protein } 1 \text { (HIPP1) }\end{array}$ & $\mathrm{N} / \mathrm{A}$ & None found & $\begin{array}{c}\text { CP190 [63] } \\
\text { dCTCF [63] } \\
\text { Pita [63] } \\
\text { Mod(mdg4) [63] } \\
\text { Su(Hw) [63] }\end{array}$ \\
\hline modifier of mdg4 (Mod(mdg4)) & $\begin{array}{c}\text { E(var)3-93D, doom, mnm, } \\
\operatorname{Mod}(\operatorname{mdg} 4) 2.2, \operatorname{Mod}(\operatorname{mdg} 4)-67.2\end{array}$ & Not directly [43] & $\begin{array}{c}\text { Chromator [85] } \\
\text { CLAMP [42] } \\
\text { CP190 [39] } \\
\text { GAF [44] } \\
\text { HIPP1 [63] } \\
\text { Su(Hw) }[56,88]\end{array}$ \\
\hline Motif 1 Binding Protein (M1BP) & $\mathrm{N} / \mathrm{A}$ & $\begin{array}{l}\text { Yes, via zinc finger } \\
\text { domains [47] }\end{array}$ & $\begin{array}{c}\text { CP190 [49] } \\
\text { Mod(mdg4) [49] } \\
\text { Su(Hw) [49] }\end{array}$ \\
\hline pita & Spdk, spotted dick & $\begin{array}{l}\text { Yes, via zinc finger } \\
\quad \text { domains [89] }\end{array}$ & $\begin{array}{l}\text { CP190 [51] } \\
\text { HIPP1 [63] } \\
\text { ZIPIC [51] }\end{array}$ \\
\hline $\begin{array}{l}\text { suppressor of Hairy } \\
\text { wing }(\mathrm{su}(\mathrm{Hw}))\end{array}$ & suHw & $\begin{array}{l}\text { Yes, via zinc finger } \\
\quad \text { domains [90] }\end{array}$ & $\begin{array}{c}\text { CLAMP [42] } \\
\text { CP190 [39] } \\
\text { E(y)2 [61] } \\
\text { HIPP1 [63] } \\
\text { Mod(mdg4) [56,88] }\end{array}$ \\
\hline Trithorax-like (Trl) & $\begin{array}{l}\text { GAF, GAGA, GAGA factor, } \\
\text { Nc70F, GAGA-factor }\end{array}$ & $\begin{array}{l}\text { Yes, via a zinc finger } \\
\text { domain [91] }\end{array}$ & $\begin{array}{c}\mathrm{E}(\mathrm{y}) 2[45] \\
\operatorname{Mod}(\operatorname{mdg} 4)[45]\end{array}$ \\
\hline zelda (zld) & vfl, vielfaltig, EP134 & $\begin{array}{l}\text { Yes, via zinc finger } \\
\text { domains [92] }\end{array}$ & Ubx [93] \\
\hline $\begin{array}{l}\text { Zinc-finger protein interacting } \\
\text { with CP190 (ZIPIC) }\end{array}$ & $\mathrm{N} / \mathrm{A}$ & $\begin{array}{l}\text { Yes, via zinc finger } \\
\text { domains [94] }\end{array}$ & $\begin{array}{l}\text { CP190 [51] } \\
\text { Pita [51] }\end{array}$ \\
\hline
\end{tabular}

\section{Interhomolog Interactions}

Just as chromosomes can interact with themselves to organize into TADs, they are also subject to complex associations with their homolog. These associations drive how homologous chromosomes pair with one another, complement each other's transcription regulation in trans, and form discrete territories within the nucleus. Interhomolog interactions are genetically and cytologically detectable in $D$. melanogaster because the chromosomes regularly pair with their homolog in somatic tissues. While interactions between homologs are also critical—and perhaps even more so-during meiosis, in this 
work, we will limit our scope to what is known about homologous chromosome pairing in somatic tissue (see Rubin et al. 2020 for a recent review of interhomolog interactions during meiosis) [95].

Homologous chromosome pairing in Drosophila somatic tissue was first visualized by Stevens and then Metz $[96,97]$ in pre-meiotic mitotic metaphases using classic cytological techniques to fix the tissue and stain for the chromosomes. Today, the physical interaction of homologs can be observed at high resolution using methods such as fluorescent in situ hybridization (FISH) or Hi-C. Additionally, the functional consequences of interhomolog interactions, particularly regulatory regions on one homolog being able to influence the expression of a target on the other, can be read out genetically. Below, we review both of these types of interhomolog interactions insofar as they have been investigated in D. melanogaster, followed by a discussion of how these interhomolog interactions drive chromosome territory formation within the nucleus.

\subsection{Homologous Chromosome Pairing in Somatic Tissue}

Cytogenetic methods to examine somatic chromosome pairing in Drosophila, similar to those employed by Stevens and Metz, can occasionally capture cells with condensed chromosomes that have yet to fully unpair homologs [96-99]. An example of the results from this technique is shown in Figure 2, where it was used to investigate the pairing dynamics of small, supernumerary B chromosomes [100]. These B chromosomes are maintained at a high copy number and are mostly - if not entirely — composed of heterochromatin [101,102], making it difficult to ascertain their pairing aptitude with other methods. As shown in Figure $2 \mathrm{a}$, tight homologous chromosome pairing between condensed chromosomes is retained primarily in the euchromatic regions (the arms) of the $X$, second, and third chromosomes. The separation of homologs is most apparent in the heterochromatin-rich regions of the larger chromosomes, particularly in the pericentromeric regions, which is consistent with previous cytogenetic pairing observations [98,99]. Both the B chromosomes and Chromosome 4 appear not to be engaged in tight homologous pairing; if heterochromatin dissolves its pairing interactions (or promotes anti-pairing) before euchromatin, then the abundance of heterochromatin on the B chromosomes and Chromosome 4 may explain why the homologs of these chromosomes have separated. Certainly, as this technique is repeated, a clearer picture of B chromosome pairing in somatic tissue will emerge.
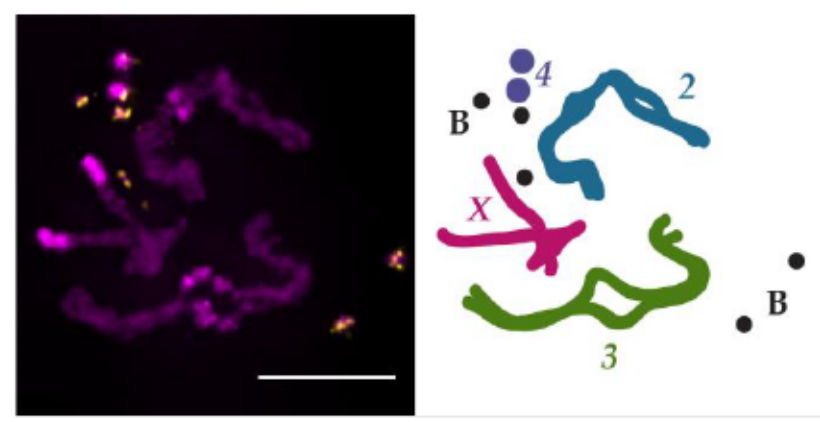

(a)
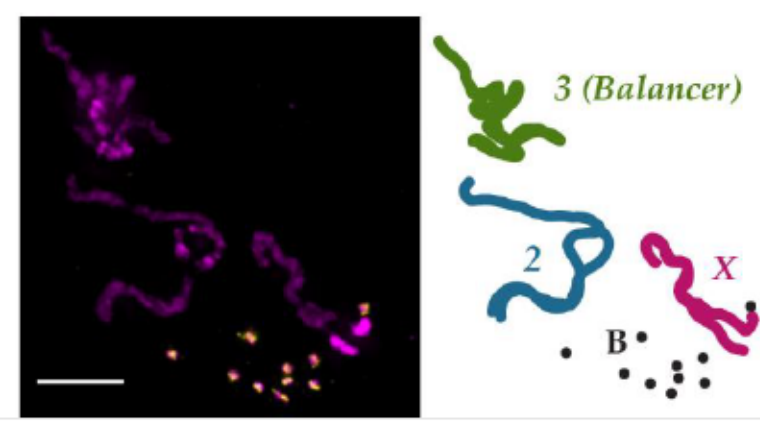

(b)

Figure 2. Homologous pairing in Drosophila melanogaster somatic cells that carry B chromosomes. (a) Tight homologous chromosome pairing between condensed chromosomes is retained primarily in the euchromatic regions. Left, metaphase chromosomes from third-instar larval neuroblasts; right, cartoon trace of each chromosome. The B chromosomes do not appear to pair. (b) Homologous chromosome pairing of a balancer chromosome (Chromosome 3), cartooned in green. The other large chromosomes exhibit normal pairing. Chromosome 4 not shown. Magenta: DNA, stained with DAPI. Yellow: fluorescent FISH probe recognizing the $A A G A T$ satellite repeat present on Chromosome 4 and the B chromosomes. Scale bar $=5 \mu \mathrm{m}[100]$.

Though assessing homolog pairing via cytogenetics can be informative, it is not a feasible approach for broad-spectrum studies of homologous chromosome pairing. The 
cytogenetic method requires cells to be in mitosis and have clearly condensed chromosomes so that each can be easily distinguished; homolog interactions that occur during interphase or in cells that have poorly condensed mitotic chromosomes would not be detected with this technique. A more modern approach to pairing assessment is the use of fluorescent in situ hybridization (FISH), which uses fluorescently labeled nucleic acid probes that are designed to hybridize with a specific sequence within the genome. When applied to an interphase cell, the FISH probe will bind to its target sequence on both homologs. If the homologs are unpaired at that location, then two FISH foci will be visible; however, the FISH signal from two paired homologs is unresolvable and appears as one focus. Using this technique, it was determined that the somatic pairing of homologs in D. melanogaster begins early in development during the embryonic mid-blastula transition, reaching an appreciable frequency of pairing by cycle 14 [103-105]. The mid-blastula transition occurs between cycles 10 and 14 and coincides with an elongation of the cell cycle and zygotic gene activation (ZGA) as part of the maternal-zygotic transition [106]. The onset of homologous chromosome pairing, however, appears not to be driven by a specific gene product expressed from the zygotic genome because embryos that were deficient for both copies of entire chromosome arms were still able to initiate pairing [107]. Thus, homolog pairing is likely a facet of the developmental program at large, which is consistent with recent studies examining the formation of TADs and the 3D genome organization that emerges during ZGA [108,109].

Though no one zygotic gene product may be responsible for initiating homolog pairing, we do know of a handful of genes that appear to promote the frequency of homologous chromosome pairing when disrupted in other tissues and in cell culture. Not surprisingly, one of these genes is $s u(H w)$, which also plays a critical role in TAD formation (as discussed above). In the absence of $\mathrm{Su}(\mathrm{Hw})$, homologous chromosome pairing in the imaginal discs is reduced by around 30\% [110]. Another gene that has been shown to be important for homolog pairing is Topoisomerase 2 (Top2), which is a type II topoisomerase that can make double-strand breaks and catenate and decatenate DNA. Disruption of Top2, either via RNAi knockdown or treatment with the topoisomerase inhibitor ICRF-193, results in a significant reduction in homolog pairing [99]. Despite its ability to directly alter the DNA topology, the pairing defects observed when the Top2 function is impaired may instead be related to its role in stabilizing $\mathrm{Su}(\mathrm{Hw})$ insulators by preventing the degradation of an isoform of $\operatorname{Mod}(\operatorname{mdg} 4)$ [111].

Just as there are genes that play a role in promoting homologous chromosome pairing, some genes appear to have the ability to antagonize it. Condensins are multi-unit, ringlike protein complexes that laterally (condensin I) and axially (condensin II) organize chromosomes [112]. A component of condensin II, Cap-H2, has been shown to be necessary for the disassembly of nurse cell polytene chromosome pairing during oogenesis, as well as sufficient to disrupt the pairing between the polytene chromosomes in salivary gland cells [113]. Activity of condensin II is negatively regulated by SCFSlimb, a ubiquitin ligase complex that targets Cap-H2 for degradation [114]. The anti-pairing action of condensin II is likely due to its promotion of axial compaction of chromatin as facilitated by the interaction between Cap-H2 and Mrg15, the latter of which acts as a loading factor [115,116].

In an effort to identify additional genes that may play a role in homologous chromosome pairing, two separate studies conducted FISH-based RNAi screens in Drosophila cell culture. Both screens were a great success (59 hits for pairing-promoting genes [117], 40 and 65 hits for pairing-promoting and anti-pairing genes, respectively [118]), and the broader conclusion that arose from these studies was that most of the hits have functional roles that are tied to cell cycle events. This connection of homolog pairing and the cell cycle is consistent with previous reports of pairing status changes through cell cycle progression $[5,99,104]$.

An even more sensitive method than FISH has recently emerged to examine homolog pairing on a genome-wide scale. Conventional $\mathrm{Hi}-\mathrm{C}$ cannot determine whether DNA fragments were derived from the maternal or the paternal homolog; therefore, it is not 
possible to differentiate interhomolog interactions from inter-sister interactions. Utilizing single-nucleotide variants (SNVs) to establish the parental haplotype, a pair of studies were able distinguish maternal from paternal chromosomes, leading to a contact map that included interhomolog interactions in early embryos [119] and clonal cell lines [120]. These studies found that interhomolog interactions varied in strength across the genome, and that pairing correlated strongly with active chromatin.

These haplotype-resolved Hi-C studies also showed that pairing was not uniform across the genome and that TADs are organized intrachromosomally but participate in homolog pairing via TAD boundaries, two observations that fit with the button model of how homologs pair (Figure 1) [121]. Indeed, this model explains why a multiply inverted balancer chromosome both has mostly (88\%) unchanged TAD boundaries [122] and can still pair with its homolog, albeit with more contortion (Figure 2B). The button model further predicts that pairing initiates at insulator-enriched TAD boundaries, but what is driving this organization? At least in early development, the sites that were found to be the most frequently paired were also enriched with Zelda (Zld). Zld, a zinc finger protein that mediates chromatin accessibility, is a key activator of transcription during ZGA [92] and is enriched at domain boundaries that are transcriptionally active [108]. This result is consistent with the observation that Zld helps establish TAD boundary insulation [108], and that insulators can act to stabilize interhomolog interactions [123,124]. Together, these studies indicate that Zld-mediated transcription during development is important for the establishment of early TAD domain boundaries, which serve as sites of robust homologous chromosome paring.

\subsection{Transvection and Interhomolog Communication}

Somatic homologous chromosome pairing results in some interesting functional consequences. Given a situation where one homolog carries a promoter and its corresponding coding region but lacks the necessary enhancer element, and on the other homolog, the enhancer element is present but the promoter and coding region it regulates is absent, classical genetics would predict that no gene product could be produced since neither homolog carries all three necessary components. In Drosophila, this is not necessarily the case due to the phenomenon of transvection [125]. The pairing of homologs in somatic tissues enables regulatory elements on one homolog to exert their effects on the opposite homolog, resulting in genetic complementation in trans and the normal expression of a gene. Several genes have been observed to be subject to trans effects in Drosophila, including Ultrabithorax (Ubx) [125], yellow (y) [126,127], decapentaplegic (dpp) [128], cubitus interruptus (ci) [129], brown (bw) [130], engrailed (en) [131], eyes absent (eya) [132], Gpdh [133], hedgehog (hh) [134], pointed (pnt) [135], sex combs reduced (scr) [136], TMR of Abd-B [137], spineless (ss) [138], vestigial (vg) [139], white (w) [140], and wingless (wg) [141].

Transvection is a type of interhomolog communication that appears to be a fortunate consequence of position-dependent homologous chromosome pairing, while other examples of interhomolog communication have been found that are not position-dependent [138] and that can occur over a long distance and be cell-type specific [142,143]. Though the local chromatin architecture may influence the level of transvection output [144], the requirement of pairing and homology in transvection is well established [126,145-148], and it appears that any enhancer can likely act on any promoter provided the two are at the same genomic position [149]. Since pairing is likely mediated by insulators, it is not surprising that insulators also play a key role in transvection. As demonstrated at the yellow locus, two paired gypsy insulators on each homologous chromosome facilitated the trans activation of the yellow promoter, implicating the gypsy insulator binding protein $\mathrm{Su}(\mathrm{Hw})$ in facilitating homologous pairing [150]. This study was echoed by a similar investigation that demonstrated gypsy insulators that flanked a reporter construct supported transvection [123]. Recently, additional studies have made it undeniably clear that insulators are required for transvection [121,151]. 


\section{Chromosome Territories and the Rabl Configuration}

With the complexity of organization at the chromosome level, it is to be expected that the genome within the nucleus is also highly organized. In Drosophila and in many other organisms, each chromosome occupies a discrete territory [152]. This arrangement was first suggested by Rabl [153] and later expanded on by Boveri, who introduced the term chromosome territory (CT) [154]. Modern methods have clearly demonstrated the presence of CTs in Drosophila using both cytological [155] and genomic [156] approaches. One benefit of CTs may be to protect the genome from aberrant repair products after suffering damage, as a loss of territory formation can lead to an increase in chromosome rearrangements [157].

Within each of these territories, pericentromeric heterochromatin has been shown to be hierarchically organized and forms into its own territories that remain near to its corresponding chromosome territory [158]. This result is consistent with chromosomes being held in a Rabl configuration, which is when the centromeres are held together at one end of the nucleus and the telomeres are positioned at the opposite end (Figure 1). Analysis by FISH confirms that chromosomes adhere to the Rabl configuration [159], as do advanced genomic methods that integrate Hi-C data with lamina-DamID experiments [156] or visualize chromosome contacts for maternal and paternal homologs in haplotyperesolved Hi-C [119].

\section{Conclusions}

From TADs to territory, the genome of Drosophila melanogaster is highly organized. Interphase chromatin is looped and folded to bring distant modulators into proximity with the genes they affect. This intrachromosomal organization is reliably re-established cell cycle after cell cycle. In Drosophila, an additional layer of organization operates through interhomolog interactions, where regions of one homolog can pair with the corresponding region on the other homolog. This pairing is mediated by proteins that also play a role in TAD formation, suggesting that the multi-scale organization we observe may be the result of a unified protein network of genome architects.

Equipped with the ability to assay chromosome contacts both genome-wide and in combination with other layers of genome data, the next decade of chromosome dynamics is sure to please. It will be exciting to investigate how genome organization changes in relation to various other critical events, such as metamorphosis and gametogenesis. One interesting question is how pairing in somatic tissue compares to the pairing observed in the female germline, and if polar mutants that affect the distribution of crossovers also affect genome organization. Another question is how small, supernumerary chromosomes pair and organize within the nucleus. The B chromosomes are less than $2 \mathrm{Mbp}$ in size and do not carry euchromatic regions [101]; therefore, the ability to pair via active chromatin within TAD boundaries is not an option. Perhaps homologous chromosome pairing has persisted due to its ability to modulate gene expression in trans; therefore, the lack of pairing of $\mathrm{B}$ chromosomes may not be consequential. Additionally, it will be interesting to uncover what mediates the homology search in interhomolog interactions. What ensures an insulator protein at one locus on a homolog is interacting with the insulator protein that is bound to the corresponding locus on the other homolog? We know that pairing proceeds by a random walk model [104], and that non-coding RNAs help regulate genome organization [160]; therefore, perhaps a chromosome's motion and non-coding RNAs combined with the accessibility of chromatin at pairing sites will be the connection. Regardless, this is an exciting time for investigations into the organization of the genome.

Author Contributions: Writing-original draft preparation, S.C.P., K.B.S. and S.L.H.; writingreview and editing, S.C.P., K.B.S. and S.L.H. All authors have read and agreed to the published version of the manuscript.

Funding: This research was funded by Eunice Kennedy Shriver National Institute of Child Health \& Human Development of the National Institutes of Health under Award Number R00HD099276 to S.L.H. 
Acknowledgments: The authors would like to thank Scott Hawley and the Stowers Institute for Medical Research for providing access to the facilities required to obtain the larval neuroblast cytogenetic images. The authors also greatly appreciate the feedback of the expert referees on this manuscript. We apologize to authors whose work we were unable to include due to length constraints.

Conflicts of Interest: The authors declare no conflict of interest. The funders had no role in the design of the study; in the collection, analyses, or interpretation of data; in the writing of the manuscript, or in the decision to publish the results. The content is solely the responsibility of the authors and does not necessarily represent the official views of the National Institutes of Health.

\section{References and Note}

1. Flemming, W. Contributions to the Knowledge of the Cell and Its Vital Processes. (Translation of "Beitrage zur Kenntniss der Zelle und Ihrer Lebenserscheinungen, Theil II" originally published in 1880 in Archivfiir Mikroskopische Anatomie, Volume 18, pages 151-259). J. Cell Biol. 1965, 25, 3-69. [CrossRef]

2. Szabo, Q.; Bantignies, F.; Cavalli, G. Principles of genome folding into topologically associating domains. Sci. Adv. 2019, 5, eaaw1668. [CrossRef] [PubMed]

3. Dame, R.T.; Rashid, F.Z.M.; Grainger, D.C. Chromosome organization in bacteria: Mechanistic insights into genome structure and function. Nat. Rev. Genet. 2020, 21, 227-242. [CrossRef]

4. Takemata, N.; Bell, S.D. Emerging views of genome organization in Archaea. J. Cell Sci. 2020, 133, jcs243782. [CrossRef]

5. Csink, A.K.; Henikoff, S. Large-scale chromosomal movements during interphase progression in Drosophila. J. Cell Biol. 1998, 143, 13-22. [CrossRef] [PubMed]

6. Marshall, W.F.; Straight, A.; Marko, J.F.; Swedlow, J.; Dernburg, A.; Belmont, A.; Murray, A.W.; Agard, D.A.; Sedat, J.W. Interphase chromosomes undergo constrained diffusional motion in living cells. Curr. Biol. 1997, 7, 930-939. [CrossRef]

7. Dekker, J.; Misteli, T. Long-range chromatin interactions. Cold Spring Harb. Perspect. Biol. 2015, 7, a019356. [CrossRef]

8. Dekker, J.; Rippe, K.; Dekker, M.; Kleckner, N. Capturing chromosome conformation. Science 2002, 295, 1306-1311. [CrossRef]

9. Lieberman-Aiden, E.; van Berkum, N.L.; Williams, L.; Imakaev, M.; Ragoczy, T.; Telling, A.; Amit, I.; Lajoie, B.R.; Sabo, P.J.; Dorschner, M.O.; et al. Comprehensive mapping of long-range interactions reveals folding principles of the human genome. Science 2009, 326, 289-293. [CrossRef] [PubMed]

10. Duan, Z.; Andronescu, M.; Schutz, K.; McIlwain, S.; Kim, Y.J.; Lee, C.; Shendure, J.; Fields, S.; Blau, C.A.; Noble, W.S. A three-dimensional model of the yeast genome. Nature 2010, 465, 363-367. [CrossRef] [PubMed]

11. Sexton, T.; Yaffe, E.; Kenigsberg, E.; Bantignies, F.; Leblanc, B.; Hoichman, M.; Parrinello, H.; Tanay, A.; Cavalli, G. Threedimensional folding and functional organization principles of the Drosophila genome. Cell 2012, 148, 458-472. [CrossRef]

12. Nora, E.P.; Lajoie, B.R.; Schulz, E.G.; Giorgetti, L.; Okamoto, I.; Servant, N.; Piolot, T.; van Berkum, N.L.; Meisig, J.; Sedat, J.; et al. Spatial partitioning of the regulatory landscape of the X-inactivation centre. Nature 2012, 485, 381-385. [CrossRef] [PubMed]

13. Dixon, J.R.; Selvaraj, S.; Yue, F.; Kim, A.; Li, Y.; Shen, Y.; Hu, M.; Liu, J.S.; Ren, B. Topological domains in mammalian genomes identified by analysis of chromatin interactions. Nature 2012, 485, 376-380. [CrossRef] [PubMed]

14. Kempfer, R.; Pombo, A. Methods for mapping 3D chromosome architecture. Nat. Rev. Genet. 2020, 21, 207-226. [CrossRef] [PubMed]

15. McKay, D.J.; Stutzman, A.V.; Dowen, J.M. Advancements in mapping 3D genome architecture. Methods 2020, 170, 75-81. [CrossRef] [PubMed]

16. Cardozo Gizzi, A.M.; Cattoni, D.I.; Fiche, J.-B.; Espinola, S.M.; Gurgo, J.; Messina, O.; Houbron, C.; Ogiyama, Y.; Papadopoulos, G.L.; Cavalli, G.; et al. Microscopy-Based Chromosome Conformation Capture Enables Simultaneous Visualization of Genome Organization and Transcription in Intact Organisms. Mol. Cell 2019, 74, 212-222.e5. [CrossRef]

17. Hsieh, T.-H.S.; Weiner, A.; Lajoie, B.; Dekker, J.; Friedman, N.; Rando, O.J. Mapping Nucleosome Resolution Chromosome Folding in Yeast by Micro-C. Cell 2015, 162, 108-119. [CrossRef] [PubMed]

18. Wang, Q.; Sun, Q.; Czajkowsky, D.M.; Shao, Z. Sub-kb Hi-C in D. melanogaster reveals conserved characteristics of TADs between insect and mammalian cells. Nat. Commun. 2018, 9, 188. [CrossRef]

19. Matthews, N.E.; White, R. Chromatin Architecture in the Fly: Living without CTCF/Cohesin Loop Extrusion?: Alternating Chromatin States Provide a Basis for Domain Architecture in Drosophila. BioEssays 2019, 41, e1900048. [CrossRef]

20. Luzhin, A.V.; Flyamer, I.M.; Khrameeva, E.E.; Ulianov, S.V.; Razin, S.V.; Gavrilov, A.A. Quantitative differences in TAD border strength underly the TAD hierarchy in Drosophila chromosomes. J. Cell. Biochem. 2019, 120, 4494-4503. [CrossRef]

21. Stadler, M.R.; Haines, J.E.; Eisen, M.B. Convergence of topological domain boundaries, insulators, and polytene interbands revealed by high-resolution mapping of chromatin contacts in the early Drosophila melanogaster embryo. Elife 2017, 6, e29550. [CrossRef]

22. Ulianov, S.V.; Zakharova, V.V.; Galitsyna, A.A.; Kos, P.I.; Polovnikov, K.E.; Flyamer, I.M.; Mikhaleva, E.A.; Khrameeva, E.E.; Germini, D.; Logacheva, M.D.; et al. Order and stochasticity in the folding of individual Drosophila genomes. Nat. Commun. 2021, 12, 41. [CrossRef] [PubMed]

23. Sun, Q.; Perez-Rathke, A.; Czajkowsky, D.M.; Shao, Z.; Liang, J. High-resolution single-cell 3D-models of chromatin ensembles during Drosophila embryogenesis. Nat. Commun. 2021, 12, 205. [CrossRef] [PubMed] 
24. Fudenberg, G.; Imakaev, M.; Lu, C.; Goloborodko, A.; Abdennur, N.; Mirny, L.A. Formation of Chromosomal Domains by Loop Extrusion. Cell Rep. 2016, 15, 2038-2049. [CrossRef]

25. Jost, D.; Carrivain, P.; Cavalli, G.; Vaillant, C. Modeling epigenome folding: Formation and dynamics of topologically associated chromatin domains. Nucleic Acids Res. 2014, 42, 9553-9561. [CrossRef] [PubMed]

26. Ulianov, S.V.; Doronin, S.A.; Khrameeva, E.E.; Kos, P.I.; Luzhin, A.V.; Starikov, S.S.; Galitsyna, A.A.; Nenasheva, V.V.; Ilyin, A.A.; Flyamer, I.M.; et al. Nuclear lamina integrity is required for proper spatial organization of chromatin in Drosophila. Nat. Commun. 2019, 10, 1176. [CrossRef]

27. Ou, H.D.; Phan, S.; Deerinck, T.J.; Thor, A.; Ellisman, M.H.; O'Shea, C.C. ChromEMT: Visualizing 3D chromatin structure and compaction in interphase and mitotic cells. Science 2017, 357, eaag0025. [CrossRef]

28. Ghosh, S.K.; Jost, D. How epigenome drives chromatin folding and dynamics, insights from efficient coarse-grained models of chromosomes. PLoS Comput. Biol. 2018, 14, e1006159. [CrossRef]

29. Ing-Simmons, E.; Vaid, R.; Bing, X.Y.; Levine, M.; Mannervik, M.; Vaquerizas, J.M. Independence of chromatin conformation and gene regulation during Drosophila dorsoventral patterning. Nat. Genet. 2021, 53, 487-499. [CrossRef]

30. Espinola, S.M.; Götz, M.; Bellec, M.; Messina, O.; Fiche, J.B.; Houbron, C.; Dejean, M.; Reim, I.; Cardozo Gizzi, A.M.; Lagha, M.; et al. Cis-regulatory chromatin loops arise before TADs and gene activation, and are independent of cell fate during early Drosophila development. Nat. Genet. 2021, 53, 477-486. [CrossRef]

31. Ulianov, S.V.; Khrameeva, E.E.; Gavrilov, A.A.; Flyamer, I.M.; Kos, P.; Mikhaleva, E.A.; Penin, A.A.; Logacheva, M.D.; Imakaev, M.V.; Chertovich, A.; et al. Active chromatin and transcription play a key role in chromosome partitioning into topologically associating domains. Genome Res. 2016, 26, 70-84. [CrossRef]

32. El-Sharnouby, S.; Fischer, B.; Magbanua, J.P.; Umans, B.; Flower, R.; Choo, S.W.; Russell, S.; White, R. Regions of very low H3K27me3 partition the Drosophila genome into topological domains. PLoS ONE 2017, 12, e0172725. [CrossRef]

33. Rowley, M.J.; Nichols, M.H.; Lyu, X.; Ando-Kuri, M.; Rivera, I.S.M.; Hermetz, K.; Wang, P.; Ruan, Y.; Corces, V.G. Evolutionarily Conserved Principles Predict 3D Chromatin Organization. Mol. Cell 2017, 67, 837-852.e7. [CrossRef]

34. Moon, H.; Filippova, G.; Loukinov, D.; Pugacheva, E.; Chen, Q.; Smith, S.T.; Munhall, A.; Grewe, B.; Bartkuhn, M.; Arnold, R.; et al. CTCF is conserved from Drosophila to humans and confers enhancer blocking of the Fab-8 insulator. EMBO Rep. 2005, 6, 165-170. [CrossRef] [PubMed]

35. Kyrchanova, O.; Maksimenko, O.; Ibragimov, A.; Sokolov, V.; Postika, N.; Lukyanova, M.; Schedl, P.; Georgiev, P. The insulator functions of the Drosophila polydactyl C2H2 zinc finger protein CTCF: Necessity versus sufficiency. Sci. Adv. 2020, 6, eaaz3152. [CrossRef]

36. Kaushal, A.; Mohana, G.; Dorier, J.; Özdemir, I.; Omer, A.; Cousin, P.; Semenova, A.; Taschner, M.; Dergai, O.; Marzetta, F.; et al. CTCF loss has limited effects on global genome architecture in Drosophila despite critical regulatory functions. Nat. Commun. 2021, 12, 1101. [CrossRef] [PubMed]

37. Zhao, K.; Hart, C.M.; Laemmli, U.K. Visualization of chromosomal domains with boundary element-associated factor BEAF-32. Cell 1995, 81, 879-889. [CrossRef]

38. Van Bortle, K.; Ramos, E.; Takenaka, N.; Yang, J.; Wahi, J.E.; Corces, V.G. Drosophila CTCF tandemly aligns with other insulator proteins at the borders of H3K27me3 domains. Genome Res. 2012, 22, 2176-2187. [CrossRef]

39. Pai, C.-Y.; Lei, E.P.; Ghosh, D.; Corces, V.G. The centrosomal protein CP190 is a component of the gypsy chromatin insulator. Mol. Cell 2004, 16, 737-748. [CrossRef]

40. Ahanger, S.H.; Günther, K.; Weth, O.; Bartkuhn, M.; Bhonde, R.R.; Shouche, Y.S.; Renkawitz, R. Ectopically tethered CP190 induces large-scale chromatin decondensation. Sci. Rep. 2014, 4, 3917. [CrossRef]

41. Bartkuhn, M.; Straub, T.; Herold, M.; Herrmann, M.; Rathke, C.; Saumweber, H.; Gilfillan, G.D.; Becker, P.B.; Renkawitz, R. Active promoters and insulators are marked by the centrosomal protein 190. EMBO J. 2009, 28, 877-888. [CrossRef]

42. Bag, I.; Dale, R.K.; Palmer, C.; Lei, E.P. The zinc-finger protein CLAMP promotes gypsy chromatin insulator function in Drosophila. J. Cell Sci. 2019, 132, jcs226092. [CrossRef]

43. Gause, M.; Morcillo, P.; Dorsett, D. Insulation of enhancer-promoter communication by a gypsy transposon insert in the Drosophila cut gene: Cooperation between suppressor of hairy-wing and modifier of mdg4 proteins. Mol. Cell. Biol. 2001, 21, $4807-4817$. [CrossRef]

44. Melnikova, L.; Juge, F.; Gruzdeva, N.; Mazur, A.; Cavalli, G.; Georgiev, P. Interaction between the GAGA factor and Mod(mdg4) proteins promotes insulator bypass in Drosophila. Proc. Natl. Acad. Sci. USA 2004, 101, 14806-14811. [CrossRef] [PubMed]

45. Lomaev, D.; Mikhailova, A.; Erokhin, M.; Shaposhnikov, A.V.; Moresco, J.J.; Blokhina, T.; Wolle, D.; Aoki, T.; Ryabykh, V.; Yates, J.R.; et al. The GAGA factor regulatory network: Identification of GAGA factor associated proteins. PLoS ONE 2017, 12, e0173602. [CrossRef] [PubMed]

46. Gaskill, M.M.; Gibson, T.J.; Larson, E.D.; Harrison, M.M. GAF is essential for zygotic genome activation and chromatin accessibility in the early Drosophila embryo. eLife 2021, 10. [CrossRef]

47. Li, J.; Gilmour, D.S. Distinct mechanisms of transcriptional pausing orchestrated by GAGA factor and M1BP, a novel transcription factor. EMBO J. 2013, 32, 1829-1841. [CrossRef] [PubMed]

48. Ramírez, F.; Bhardwaj, V.; Arrigoni, L.; Lam, K.C.; Grüning, B.A.; Villaveces, J.; Habermann, B.; Akhtar, A.; Manke, T. Highresolution TADs reveal DNA sequences underlying genome organization in flies. Nat. Commun. 2018, 9, 189. [CrossRef] [PubMed] 
49. Bag, I.; Chen, S.; Rosin, L.F.; Chen, Y.; Liu, C.-Y.; Yu, G.-Y.; Lei, E.P. M1BP cooperates with CP190 to activate transcription at TAD borders and promote chromatin insulator activity. bioRxiv 2020. [CrossRef]

50. Gaszner, M.; Vazquez, J.; Schedl, P. The Zw5 protein, a component of the scs chromatin domain boundary, is able to block enhancer-promoter interaction. Genes Dev. 1999, 13, 2098-2107. [CrossRef]

51. Maksimenko, O.; Bartkuhn, M.; Stakhov, V.; Herold, M.; Zolotarev, N.; Jox, T.; Buxa, M.K.; Kirsch, R.; Bonchuk, A.; Fedotova, A.; et al. Two new insulator proteins, Pita and ZIPIC, target CP190 to chromatin. Genome Res. 2015, 25, 89-99. [CrossRef] [PubMed]

52. Nègre, N.; Brown, C.D.; Shah, P.K.; Kheradpour, P.; Morrison, C.A.; Henikoff, J.G.; Feng, X.; Ahmad, K.; Russell, S.; White, R.A.H.; et al. A comprehensive map of insulator elements for the Drosophila genome. PLoS Genet. 2010, 6, e1000814. [CrossRef] [PubMed]

53. Jiang, N.; Emberly, E.; Cuvier, O.; Hart, C.M. Genome-wide mapping of boundary element-associated factor (BEAF) binding sites in Drosophila melanogaster links BEAF to transcription. Mol. Cell. Biol. 2009, 29, 3556-3568. [CrossRef]

54. Yang, J.; Ramos, E.; Corces, V.G. The BEAF-32 insulator coordinates genome organization and function during the evolution of Drosophila species. Genome Res. 2012, 22, 2199-2207. [CrossRef]

55. Vorobyeva, N.E.; Mazina, M.U.; Golovnin, A.K.; Kopytova, D.V.; Gurskiy, D.Y.; Nabirochkina, E.N.; Georgieva, S.G.; Georgiev, P.G.; Krasnov, A.N. Insulator protein $\mathrm{Su}(\mathrm{Hw})$ recruits SAGA and Brahma complexes and constitutes part of Origin Recognition Complex-binding sites in the Drosophila genome. Nucleic Acids Res. 2013, 41, 5717-5730. [CrossRef] [PubMed]

56. Georgiev, P.; Kozycina, M. Interaction between mutations in the suppressor of Hairy wing and modifier of mdg4 genes of Drosophila melanogaster affecting the phenotype of gypsy-induced mutations. Genetics 1996, 142, 425-436. [CrossRef]

57. Geyer, P.K.; Corces, V.G. DNA position-specific repression of transcription by a Drosophila zinc finger protein. Genes Dev. 1992, 6, 1865-1873. [CrossRef]

58. Melnikova, L.; Kostyuchenko, M.; Molodina, V.; Parshikov, A.; Georgiev, P.; Golovnin, A. Multiple interactions are involved in a highly specific association of the Mod(mdg4)-67.2 isoform with the Su(Hw) sites in Drosophila. Open Biol. 2017, 7, 170150. [CrossRef]

59. Melnikova, L.; Kostyuchenko, M.; Parshikov, A.; Georgiev, P.; Golovnin, A. Role of Su(Hw) zinc finger 10 and interaction with CP190 and Mod(mdg4) proteins in recruiting the Su(Hw) complex to chromatin sites in Drosophila. PLoS ONE 2018, 13, e0193497. [CrossRef] [PubMed]

60. Kyrchanova, O.; Maksimenko, O.; Stakhov, V.; Ivlieva, T.; Parshikov, A.; Studitsky, V.M.; Georgiev, P. Effective blocking of the white enhancer requires cooperation between two main mechanisms suggested for the insulator function. PLoS Genet. 2013, 9, e1003606. [CrossRef]

61. Kurshakova, M.; Maksimenko, O.; Golovnin, A.; Pulina, M.; Georgieva, S.; Georgiev, P.; Krasnov, A. Evolutionarily conserved $\mathrm{E}(\mathrm{y}) 2 /$ Sus1 protein is essential for the barrier activity of $\mathrm{Su}(\mathrm{Hw})$-dependent insulators in Drosophila. Mol. Cell 2007, 27, 332-338. [CrossRef] [PubMed]

62. Parnell, T.J.; Viering, M.M.; Skjesol, A.; Helou, C.; Kuhn, E.J.; Geyer, P.K. An endogenous suppressor of hairy-wing insulator separates regulatory domains in Drosophila. Proc. Natl. Acad. Sci. USA 2003, 100, 13436-13441. [CrossRef]

63. Alekseyenko, A.A.; Gorchakov, A.A.; Zee, B.M.; Fuchs, S.M.; Kharchenko, P.V.; Kuroda, M.I. Heterochromatin-associated interactions of Drosophila HP1a with dADD1, HIPP1, and repetitive RNAs. Genes Dev. 2014, 28, 1445-1460. [CrossRef] [PubMed]

64. Gerasimova, T.I.; Byrd, K.; Corces, V.G. A chromatin insulator determines the nuclear localization of DNA. Mol. Cell 2000, 6, 1025-1035. [CrossRef]

65. Byrd, K.; Corces, V.G. Visualization of chromatin domains created by the gypsy insulator of Drosophila. J. Cell Biol. 2003, 162, 565-574. [CrossRef]

66. Kaye, E.G.; Kurbidaeva, A.; Wolle, D.; Aoki, T.; Schedl, P.; Larschan, E. Drosophila Dosage Compensation Loci Associate with a Boundary-Forming Insulator Complex. Mol. Cell. Biol. 2017, 37, e00253-17. [CrossRef] [PubMed]

67. Wolle, D.; Cleard, F.; Aoki, T.; Deshpande, G.; Schedl, P.; Karch, F. Functional Requirements for Fab-7 Boundary Activity in the Bithorax Complex. Mol. Cell. Biol. 2015, 35, 3739-3752. [CrossRef] [PubMed]

68. Lanzuolo, C.; Roure, V.; Dekker, J.; Bantignies, F.; Orlando, V. Polycomb response elements mediate the formation of chromosome higher-order structures in the bithorax complex. Nat. Cell Biol. 2007, 9, 1167-1174. [CrossRef]

69. Mihaly, J.; Hogga, I.; Gausz, J.; Gyurkovics, H.; Karch, F. In situ dissection of the Fab-7 region of the bithorax complex into a chromatin domain boundary and a Polycomb-response element. Development 1997, 124, 1809-1820. [CrossRef] [PubMed]

70. Zhou, J.; Barolo, S.; Szymanski, P.; Levine, M. The Fab-7 element of the bithorax complex attenuates enhancer-promoter interactions in the Drosophila embryo. Genes Dev. 1996, 10, 3195-3201. [CrossRef] [PubMed]

71. Aoki, T.; Sarkeshik, A.; Yates, J.; Schedl, P. Elba, a novel developmentally regulated chromatin boundary factor is a hetero-tripartite DNA binding complex. eLife 2012, 1, e00171. [CrossRef]

72. Gambetta, M.C.; Furlong, E.E.M. The Insulator Protein CTCF Is Required for Correct Hox Gene Expression, but Not for Embryonic Development in Drosophila. Genetics 2018, 210, 129-136. [CrossRef] [PubMed]

73. Franke, A.; Baker, B.S. The rox1 and rox2 RNAs are essential components of the compensasome, which mediates dosage compensation in Drosophila. Mol. Cell 1999, 4, 117-122. [CrossRef]

74. Ramírez, F.; Lingg, T.; Toscano, S.; Lam, K.C.; Georgiev, P.; Chung, H.-R.; Lajoie, B.R.; de Wit, E.; Zhan, Y.; de Laat, W.; et al. High-Affinity Sites Form an Interaction Network to Facilitate Spreading of the MSL Complex across the X Chromosome in Drosophila. Mol. Cell 2015, 60, 146-162. [CrossRef] [PubMed] 
75. Quinn, J.J.; Ilik, I.A.; Qu, K.; Georgiev, P.; Chu, C.; Akhtar, A.; Chang, H.Y. Revealing long noncoding RNA architecture and functions using domain-specific chromatin isolation by RNA purification. Nat. Biotechnol. 2014, 32, 933-940. [CrossRef] [PubMed]

76. Mendjan, S.; Taipale, M.; Kind, J.; Holz, H.; Gebhardt, P.; Schelder, M.; Vermeulen, M.; Buscaino, A.; Duncan, K.; Mueller, J.; et al. Nuclear pore components are involved in the transcriptional regulation of dosage compensation in Drosophila. Mol. Cell 2006, 21, 811-823. [CrossRef]

77. Rath, U.; Ding, Y.; Deng, H.; Qi, H.; Bao, X.; Zhang, W.; Girton, J.; Johansen, J.; Johansen, K.M. The chromodomain protein, Chromator, interacts with JIL-1 kinase and regulates the structure of Drosophila polytene chromosomes. J. Cell Sci. 2006, 119, 2332-2341. [CrossRef]

78. Larkin, A.; Marygold, S.J.; Antonazzo, G.; Attrill, H.; Dos Santos, G.; Garapati, P.V.; Goodman, J.L.; Gramates, L.S.; Millburn, G.; Strelets, V.B.; et al. FlyBase: Updates to the Drosophila melanogaster knowledge base. Nucleic Acids Res. 2021, 49, D899-D907. [CrossRef] [PubMed]

79. Aravind, L. The BED finger, a novel DNA-binding domain in chromatin-boundary-element-binding proteins and transposases. Trends Biochem. Sci. 2000, 25, 421-423. [CrossRef]

80. Hart, C.M.; Zhao, K.; Laemmli, U.K. The scs' boundary element: Characterization of boundary element-associated factors. Mol. Cell. Biol. 1997, 17, 999-1009. [CrossRef]

81. Vogelmann, J.; Le Gall, A.; Dejardin, S.; Allemand, F.; Gamot, A.; Labesse, G.; Cuvier, O.; Nègre, N.; Cohen-Gonsaud, M.; Margeat, E.; et al. Chromatin insulator factors involved in long-range DNA interactions and their role in the folding of the Drosophila genome. PLoS Genet. 2014, 10, e1004544. [CrossRef] [PubMed]

82. Mohan, M.; Bartkuhn, M.; Herold, M.; Philippen, A.; Heinl, N.; Bardenhagen, I.; Leers, J.; White, R.A.H.; Renkawitz-Pohl, R.; Saumweber, H.; et al. The Drosophila insulator proteins CTCF and CP190 link enhancer blocking to body patterning. EMBO J. 2007, 26, 4203-4214. [CrossRef]

83. Soruco, M.M.L.; Chery, J.; Bishop, E.P.; Siggers, T.; Tolstorukov, M.Y.; Leydon, A.R.; Sugden, A.U.; Goebel, K.; Feng, J.; Xia, P.; et al. The CLAMP protein links the MSL complex to the X chromosome during Drosophila dosage compensation. Genes Dev. 2013, 27, 1551-1556. [CrossRef] [PubMed]

84. Bohla, D.; Herold, M.; Panzer, I.; Buxa, M.K.; Ali, T.; Demmers, J.; Krüger, M.; Scharfe, M.; Jarek, M.; Bartkuhn, M.; et al. A functional insulator screen identifies NURF and dREAM components to be required for enhancer-blocking. PLoS ONE 2014, 9, e107765. [CrossRef]

85. Golovnin, A.K.; Shapovalov, I.S.; Kostyuchenko, M.V.; Shamsutdinov, M.F.; Georgiev, P.G.; Melnikova, L.S. Chromator protein directly interacts with the common part of the Drosophila melanogaster Mod(mdg4) family proteins. Dokl. Biochem. Biophys. 2014, 454, 21-24. [CrossRef] [PubMed]

86. Maksimenko, O.; Kyrchanova, O.; Bonchuk, A.; Stakhov, V.; Parshikov, A.; Georgiev, P. Highly conserved ENY2/Sus1 protein binds to Drosophila CTCF and is required for barrier activity. Epigenetics 2014, 9, 1261-1270. [CrossRef]

87. Zolotarev, N.A.; Maksimenko, O.G.; Georgiev, P.G.; Bonchuk, A.N. ZAD-domain is essential for nuclear localization of insulator proteins in Drosophila melanogaster. Acta Nat. 2016, 8, 97-102. [CrossRef]

88. Ghosh, D.; Gerasimova, T.I.; Corces, V.G. Interactions between the $\mathrm{Su}(\mathrm{Hw})$ and $\mathrm{Mod}(\mathrm{mdg} 4)$ proteins required for gypsy insulator function. EMBO J. 2001, 20, 2518-2527. [CrossRef] [PubMed]

89. Laundrie, B.; Peterson, J.S.; Baum, J.S.; Chang, J.C.; Fileppo, D.; Thompson, S.R.; McCall, K. Germline cell death is inhibited by P-element insertions disrupting the dcp-1/pita nested gene pair in Drosophila. Genetics 2003, 165, 1881-1888. [CrossRef]

90. Parkhurst, S.M.; Harrison, D.A.; Remington, M.P.; Spana, C.; Kelley, R.L.; Coyne, R.S.; Corces, V.G. The Drosophila su(Hw) gene, which controls the phenotypic effect of the gypsy transposable element, encodes a putative DNA-binding protein. Genes Dev. 1988, 2, 1205-1215. [CrossRef]

91. Soeller, W.C.; Oh, C.E.; Kornberg, T.B. Isolation of cDNAs encoding the Drosophila GAGA transcription factor. Mol. Cell. Biol. 1993, 13, 7961-7970. [CrossRef]

92. Liang, H.-L.; Nien, C.-Y.; Liu, H.-Y.; Metzstein, M.M.; Kirov, N.; Rushlow, C. The zinc-finger protein Zelda is a key activator of the early zygotic genome in Drosophila. Nature 2008, 456, 400-403. [CrossRef]

93. Carnesecchi, J.; Sigismondo, G.; Domsch, K.; Baader, C.E.P.; Rafiee, M.-R.; Krijgsveld, J.; Lohmann, I. Multi-level and lineagespecific interactomes of the Hox transcription factor Ubx contribute to its functional specificity. Nat. Commun. 2020, 11, 1388. [CrossRef] [PubMed]

94. Krystel, J.; Ayyanathan, K. Global analysis of target genes of 21 members of the ZAD transcription factor family in Drosophila melanogaster. Gene 2013, 512, 373-382. [CrossRef] [PubMed]

95. Rubin, T.; Macaisne, N.; Huynh, J.-R. Mixing and Matching Chromosomes during Female Meiosis. Cells 2020, 9, 696. [CrossRef]

96. Stevens, N.M. A study of the germ cells of certain diptera, with reference to the heterochromosomes and the phenomena of synapsis. J. Exp. Zool. 1908, 5, 359-374. [CrossRef]

97. Metz, C.W. Chromosome studies on the Diptera. II. The paired association of chromosomes in the Diptera, and its significance. J. Exp. Zool. 1916, 21, 213-279. [CrossRef]

98. Halfer, C.; Barigozzi, C. Prophase synapsis in somatic cells of Drosophila melanogaster. Chromosom. Today 1973, 4, $181-186$.

99. Williams, B.R.; Bateman, J.R.; Novikov, N.D.; Wu, C.T. Disruption of topoisomerase II perturbs pairing in Drosophila cell culture. Genetics 2007, 177, 31-46. [CrossRef]

100. Larval neuroblast preparations were performed as previously described in Hanlon et al., 2018 [101]. 
101. Hanlon, S.L.; Miller, D.E.; Eche, S.; Hawley, R.S. Origin, composition, and structure of the supernumerary B chromosome of Drosophila melanogaster. Genetics 2018, 210, 1197-1212. [CrossRef]

102. Bauerly, E.; Hughes, S.E.; Vietti, D.R.; Miller, D.E.; McDowell, W.; Scott Hawley, R. Discovery of supernumerary B chromosomes in Drosophila melanogaster. Genetics 2014, 196, 1007-1016. [CrossRef]

103. Hiraoka, Y.; Dernburg, A.F.; Parmelee, S.J.; Rykowski, M.C.; Agard, D.A.; Sedat, J.W. The onset of homologous chromosome pairing during Drosophila melanogaster embryogenesis. J. Cell Biol. 1993, 120, 591-600. [CrossRef] [PubMed]

104. Fung, J.C.; Marshall, W.F.; Dernburg, A.; Agard, D.A.; Sedat, J.W. Homologous Chromosome Pairing in Drosophila melanogaster Proceeds through Multiple Independent Initiations. J. Cell Biol. 1998, 141, 5-20. [CrossRef] [PubMed]

105. Gemkow, M.J.; Verveer, P.J.; Arndt-Jovin, D.J. Homologous association of the Bithorax-Complex during embryogenesis: Consequences for transvection in Drosophila melanogaster. Development 1998, 125, 4541-4552. [CrossRef] [PubMed]

106. Farrell, J.A.; O'Farrell, P.H. From egg to gastrula: How the cell cycle is remodeled during the Drosophila mid-blastula transition. Annu. Rev. Genet. 2014, 48, 269-294. [CrossRef]

107. Bateman, J.R.; Wu, C.T. A genomewide survey argues that every zygotic gene product is dispensable for the initiation of somatic homolog pairing in Drosophila. Genetics 2008, 180, 1329-1342. [CrossRef]

108. Hug, C.B.; Grimaldi, A.G.; Kruse, K.; Vaquerizas, J.M. Chromatin Architecture Emerges during Zygotic Genome Activation Independent of Transcription. Cell 2017, 169, 216-228.e19. [CrossRef]

109. Ogiyama, Y.; Schuettengruber, B.; Papadopoulos, G.L.; Chang, J.M.; Cavalli, G. Polycomb-Dependent Chromatin Looping Contributes to Gene Silencing during Drosophila Development. Mol. Cell 2018, 71, 73-88.e5. [CrossRef]

110. Fritsch, C.; Ploeger, G.; Arndt-Jovin, D.J. Drosophila under the lens: Imaging from chromosomes to whole embryos. Chromosom. Res. 2006, 14, 451-464. [CrossRef]

111. Ramos, E.; Torre, E.A.; Bushey, A.M.; Gurudatta, B.V.; Corces, V.G. DNA Topoisomerase II modulates insulator function in Drosophila. PLoS ONE 2011, 6, e16562. [CrossRef]

112. Hirano, T. Condensin-Based Chromosome Organization from Bacteria to Vertebrates. Cell 2016, 164, 847-857. [CrossRef]

113. Hartl, T.A.; Smith, H.F.; Bosco, G. Chromosome alignment and transvection are antagonized by condensin II. Science 2008, 322, 1384-1387. [CrossRef]

114. Buster, D.W.; Daniel, S.G.; Nguyen, H.Q.; Windler, S.L.; Skwarek, L.C.; Peterson, M.; Roberts, M.; Meserve, J.H.; Hart, T.; Klebba, J.E.; et al. SCFSlimb ubiquitin ligase suppresses condensin II-mediated nuclear reorganization by degrading Cap-H2. J. Cell Biol. 2013, 201, 49-63. [CrossRef] [PubMed]

115. Bauer, C.R.; Hartl, T.A.; Bosco, G. Condensin II Promotes the Formation of Chromosome Territories by Inducing Axial Compaction of Polyploid Interphase Chromosomes. PLoS Genet. 2012, 8, e1002873. [CrossRef] [PubMed]

116. Wallace, H.A.; Klebba, J.E.; Kusch, T.; Rogers, G.C.; Bosco, G. Condensin II regulates interphase chromatin organization through the Mrg-binding motif of Cap-H ${ }_{2}$. G3 Genes Genomes Genet. 2015, 5, 803-817. [CrossRef]

117. Bateman, J.R.; Larschan, E.; D'Souza, R.; Marshall, L.S.; Dempsey, K.E.; Johnson, J.E.; Mellone, B.G.; Kuroda, M.I. A genome-wide screen identifies genes that affect somatic homolog pairing in Drosophila. G3 Genes Genomes Genet. 2012, 2, 731-740. [CrossRef]

118. Joyce, E.F.; Williams, B.R.; Xie, T.; Wu, C.-T. Identification of genes that promote or antagonize somatic homolog pairing using a high-throughput FISH-based screen. PLoS Genet. 2012, 8. [CrossRef] [PubMed]

119. Erceg, J.; AlHaj Abed, J.; Goloborodko, A.; Lajoie, B.R.; Fudenberg, G.; Abdennur, N.; Imakaev, M.; McCole, R.B.; Nguyen, S.C.; Saylor, W.; et al. The genome-wide multi-layered architecture of chromosome pairing in early Drosophila embryos. Nat. Commun. 2019, 10, 4486. [CrossRef]

120. AlHaj Abed, J.; Erceg, J.; Goloborodko, A.; Nguyen, S.C.; McCole, R.B.; Saylor, W.; Fudenberg, G.; Lajoie, B.R.; Dekker, J.; Mirny, L.A.; et al. Highly structured homolog pairing reflects functional organization of the Drosophila genome. Nat. Commun. 2019, 10, 4485. [CrossRef]

121. Viets, K.; Sauria, M.E.G.; Chernoff, C.; Rodriguez Viales, R.; Echterling, M.; Anderson, C.; Tran, S.; Dove, A.; Goyal, R.; Voortman, L.; et al. Characterization of Button Loci that Promote Homologous Chromosome Pairing and Cell-Type-Specific Interchromosomal Gene Regulation. Dev. Cell 2019, 51, 341-356.e7. [CrossRef]

122. Ghavi-Helm, Y.; Jankowski, A.; Meiers, S.; Viales, R.R.; Korbel, J.O.; Furlong, E.E.M. Highly rearranged chromosomes reveal uncoupling between genome topology and gene expression. Nat. Genet. 2019, 51, 1272-1282. [CrossRef] [PubMed]

123. Schoborg, T.; Kuruganti, S.; Rickels, R.; Labrador, M. The Drosophila gypsy insulator supports transvection in the presence of the vestigial enhancer. PLoS ONE 2013, 8, e81331. [CrossRef]

124. Lim, B.; Heist, T.; Levine, M.; Fukaya, T. Visualization of Transvection in Living Drosophila embryos. Mol. Cell 2018, 70, 287-296.e6. [CrossRef] [PubMed]

125. Lewis, E.B. The Theory and Application of a New Method of Detecting Chromosomal Rearrangements in Drosophila melanogaster. Am. Nat. 1954, 88, 225-239. [CrossRef]

126. Geyer, P.K.; Green, M.M.; Corces, V.G. Tissue-specific transcriptional enhancers may act in trans on the gene located in the homologous chromosome: The molecular basis of transvection in Drosophila. EMBO J. 1990, 9, 2247-2256. [CrossRef]

127. Morris, J.R.; Chen, J.; Filandrinos, S.T.; Dunn, R.C.; Fisk, R.; Geyer, P.K.; Wu, C. An analysis of transvection at the yellow locus of Drosophila melanogaster. Genetics 1999, 151, 633-651. [CrossRef]

128. Gelbart, W.M. Synapsis-dependent allelic complementation at the decapentaplegic gene complex in Drosophila melanogaster. Proc. Natl. Acad. Sci. USA 1982, 79, 2636-2640. [CrossRef] 
129. Locke, J.; Tartof, K.D. Molecular analysis of cubitus interruptus (ci) mutations suggests an explanation for the unusual ci position effects. Mol. Gen. Genet. 1994, 243, 234-243. [CrossRef]

130. Henikoff, S.; Dreesen, T.D. Trans-inactivation of the Drosophila brown gene: Evidence for transcriptional repression and somatic pairing dependence. Proc. Natl. Acad. Sci. USA 1989, 86, 6704-6708. [CrossRef] [PubMed]

131. Condie, J.M.; Brower, D.L. Allelic interactions at the engrailed locus of Drosophila: Engrailed protein expression in imaginal discs. Dev. Biol. 1989, 135, 31-42. [CrossRef]

132. Zimmerman, J.E.; Bui, Q.T.; Liu, H.; Bonini, N.M. Molecular genetic analysis of Drosophila eyes absent mutants reveals an eye enhancer element. Genetics 2000, 154, 237-246. [CrossRef]

133. Gibson, J.B.; Reed, D.S.; Bartoszewski, S.; Wilks, A. V Structural changes in the promoter region mediate transvection at the sn-glycerol-3-phosphate dehydrogenase gene of Drosophila melanogaster. Biochem. Genet. 1999, 37, 301-315. [CrossRef]

134. Lee, J.J.; von Kessler, D.P.; Parks, S.; Beachy, P.A. Secretion and localized transcription suggest a role in positional signaling for products of the segmentation gene hedgehog. Cell 1992, 71, 33-50. [CrossRef]

135. Scholz, H.; Deatrick, J.; Klaes, A.; Klämbt, C. Genetic dissection of pointed, a Drosophila gene encoding two ETS-related proteins. Genetics 1993, 135, 455-468. [CrossRef] [PubMed]

136. Southworth, J.W.; Kennison, J.A. Transvection and silencing of the Scr homeotic gene of Drosophila melanogaster. Genetics 2002, 161, 733-746. [CrossRef]

137. Ronshaugen, M.; Levine, M. Visualization of trans-homolog enhancer-promoter interactions at the Abd-B hox locus in the Drosophila embryo. Dev. Cell 2004, 7, 925-932. [CrossRef]

138. Johnston, R.J.; Desplan, C. Interchromosomal communication coordinates intrinsically stochastic expression between alleles. Science 2014, 343, 661-665. [CrossRef] [PubMed]

139. Williams, J.A.; Bell, J.B.; Carroll, S.B. Control of Drosophila wing and haltere development by the nuclear vestigial gene product. Genes Dev. 1991, 5, 2481-2495. [CrossRef] [PubMed]

140. Babu, P.; Bhat, S. Effect of zeste on white complementation. Basic Life Sci. 1980, 16, 35-40. [CrossRef] [PubMed]

141. Buratovich, M.A.; Phillips, R.G.; Whittle, J.R. Genetic relationships between the mutations spade and Sternopleural and the wingless gene in Drosophila development. Dev. Biol. 1997, 185, 244-260. [CrossRef] [PubMed]

142. Bantignies, F.; Grimaud, C.; Lavrov, S.; Gabut, M.; Cavalli, G. Inheritance of polycomb-dependent chromosomal interactions in Drosophila. Genes Dev. 2003, 17, 2406-2420. [CrossRef] [PubMed]

143. Vazquez, J.; Müller, M.; Pirrotta, V.; Sedat, J.W. The Mcp element mediates stable long-range chromosome-chromosome interactions in Drosophila. Mol. Biol. Cell 2006, 17, 2158-2165. [CrossRef] [PubMed]

144. King, T.D.; Johnson, J.E.; Bateman, J.R. Position Effects Influence Transvection in Drosophila melanogaster. Genetics 2019, 213, 1289-1299. [CrossRef] [PubMed]

145. Goldsborough, A.S.; Kornberg, T.B. Reduction of transcription by homologue asynapsis in Drosophila imaginal discs. Nature 1996, 381, 807-810. [CrossRef]

146. Chen, J.L.; Huisinga, K.L.; Viering, M.M.; Ou, S.A.; Wu, C.T.; Geyer, P.K. Enhancer action in trans is permitted throughout the Drosophila genome. Proc. Natl. Acad. Sci. USA 2002, 99, 3723-3728. [CrossRef]

147. Ou, S.A.; Chang, E.; Lee, S.; So, K.; Wu, C.T.; Morris, J.R. Effects of chromosomal rearrangements on transvection at the yellow gene of Drosophila melanogaster. Genetics 2009, 183, 483-496. [CrossRef]

148. Tian, K.; Henderson, R.E.; Parker, R.; Brown, A.; Johnson, J.E.; Bateman, J.R. Two modes of transvection at the eyes absent gene of Drosophila demonstrate plasticity in transcriptional regulatory interactions in cis and in trans. PLoS Genet. 2019, 15, e1008152. [CrossRef]

149. Blick, A.J.; Mayer-Hirshfeld, I.; Malibiran, B.R.; Cooper, M.A.; Martino, P.A.; Johnson, J.E.; Bateman, J.R. The capacity to act in trans varies among Drosophila enhancers. Genetics 2016, 203, 203-218. [CrossRef]

150. Kravchenko, E.; Savitskaya, E.; Kravchuk, O.; Parshikov, A.; Georgiev, P.; Savitsky, M. Pairing between gypsy insulators facilitates the enhancer action in trans throughout the Drosophila genome. Mol. Cell. Biol. 2005, 25, 9283-9291. [CrossRef]

151. Piwko, P.; Vitsaki, I.; Livadaras, I.; Delidakis, C. The Role of Insulators in Transgene Transvection in Drosophila. Genetics 2019, 212, 489-508. [CrossRef]

152. Cremer, T.; Cremer, M. Chromosome territories. Cold Spring Harb. Perspect. Biol. 2010, 2, a003889. [CrossRef]

153. Rabl, C. Über Zellteilung. Morphol. Jahrb. 1885, 214-330.

154. Boveri, T. Die Blastomerenkerne von Ascaris megalocephala und die Theorie der Chromosomenindividualität. Arch. Zellforsch. 1909, 3, 181-268.

155. Rosin, L.F.; Nguyen, S.C.; Joyce, E.F. Condensin II drives large-scale folding and spatial partitioning of interphase chromosomes in Drosophila nuclei. PLoS Genet. 2018, 14, e1007393. [CrossRef] [PubMed]

156. Li, Q.; Tjong, H.; Li, X.; Gong, K.; Zhou, X.J.; Chiolo, I.; Alber, F. The three-dimensional genome organization of Drosophila melanogaster through data integration. Genome Biol. 2017, 18, 145. [CrossRef] [PubMed]

157. Rosin, L.F.; Crocker, O.; Isenhart, R.L.; Nguyen, S.C.; Xu, Z.; Joyce, E.F. Chromosome territory formation attenuates the translocation potential of cells. eLife 2019, 8, e49553. [CrossRef] [PubMed]

158. Lee, Y.C.G.; Ogiyama, Y.; Martins, N.M.C.; Beliveau, B.J.; Acevedo, D.; Wu, C.-T.; Cavalli, G.; Karpen, G.H. Pericentromeric heterochromatin is hierarchically organized and spatially contacts H3K9me2 islands in euchromatin. PLoS Genet. 2020, 16, e1008673. [CrossRef] 
159. Marshall, W.F.; Dernburg, A.F.; Harmon, B.; Agard, D.A.; Sedat, J.W. Specific interactions of chromatin with the nuclear envelope: Positional determination within the nucleus in Drosophila melanogaster. Mol. Biol. Cell 1996, 7, 825-842. [CrossRef]

160. Khosraviani, N.; Ostrowski, L.A.; Mekhail, K. Roles for Non-coding RNAs in Spatial Genome Organization. Front. Cell Dev. Biol. 2019, 7, 336. [CrossRef] [PubMed] 